\section{OPEN ACCESS}

Edited by:

Allison E. Ray,

Idaho National Laboratory (DOE),

United States

Reviewed by:

Zhi-Hua Liu,

Texas A\&M University, United States

Héctor A. Ruiz,

Universidad Autónoma de Coahuila,

Mexico

${ }^{*}$ Correspondence: Michael R. Ladisch ladisch@purdue.edu

Specialty section:

This article was submitted to Bioenergy and Biofuels,

a section of the journal

Frontiers in Energy Research

Received: 14 December 2021

Accepted: 27 January 2022

Published: 17 February 2022

Citation:

Bordignon SE, Ximenes E, Perrone OM, Carreira Nunes CdC,

Kim D, Boscolo M, Gomes E, Filho EXF, da Silva $R$ and Ladisch MR

(2022) Combined Sugarcane

Pretreatment for the Generation of

Ethanol and Value-Added Products.

Front. Energy Res. 10:834966.

doi: 10.3389/fenrg.2022.834966

\title{
Combined Sugarcane Pretreatment for the Generation of Ethanol and Value-Added Products
}

\begin{abstract}
Sidnei Emilio Bordignon ${ }^{1}$, Eduardo Ximenes ${ }^{2}$, Olavo Micali Perrone ${ }^{3}$, Christiane da Costa Carreira Nunes ${ }^{1}$, Daehwan Kim ${ }^{4}$, Maurício Boscolo ${ }^{3}$, Eleni Gomes ${ }^{1}$, Edivaldo Ximenes Ferreira Filho ${ }^{5}$, Roberto da Silva ${ }^{1}$ and Michael R. Ladisch ${ }^{2 *}$

${ }^{1}$ Laboratory of Biochemistry and Applied Microbiology, Department of Food Engineering and Science, UNESP-University Estadual Paulista-IBILCE, Sao José do Rio Preto, Brazil, ${ }^{2}$ Laboratory of Renewable Resources Engineering, Department of Agricultural and Biological Engineering, Purdue University, West Lafayette, IN, United States, ${ }^{3}$ Laboratory of Sucrochemistry and Analytical Chemistry, Department of Chemistry and Environmental Sciences, UNESP-University Estadual Paulista - IBILCE, Sao José do Rio Preto, Brazil, ${ }^{4}$ Hodson Science and Technology Center, Department of Biology, Hood College, Frederick, Brazil,

${ }^{5}$ Laboratory of Enzymology, Department of Cellular Biology, University of Brasilia, Brasilia, Brazil
\end{abstract}

In this work, we have tested individual and combination of applications of ozonolysis and liquid hot water (LHW) to pretreat sugarcane bagasse (SCB) for the removal of enzyme and/or microbial inhibitors and generation of potential value-added chemicals. A solid content with $80 \%$ cellulose and a liquid phase (liquor) rich in phenolic derived compounds $\left(3 \mathrm{gL}^{-1}\right)$ from lignin, sugars $\left(>20 \mathrm{gL}^{-1}\right)$, and other compounds, such as furfural and hydroxymethylfurfural (HMF), were generated. Maximal (59\%) glucan conversion occurred in the presence of double-pretreated bagasse, which had 32-50\% more glucan available than the samples that were individually LHW or ozone-pretreated, resulting in maximal ethanol production ( $92 \%$ after $42 \mathrm{~h}$ ) from double-pretreated SCB enzyme hydrolyzate. In summary, this work showed that ozone reacts effectively with lignin without the use of any other chemical reagent, and LHW pretreatment, followed by a washing step, was effective in solubilizing and cleaning up the fiber enzyme and microbial inhibitory compounds with ozone being effective against phenolics. Moreover, the generated cellulose-rich substrate is readily fermentable. The acidic liquor fraction removed by sequential washings and containing mainly sugars and phenolic compounds may be evaluated for use in green chemistry bioconversions processes.

Keywords: ozone, liquid hot water, pretreatment, enzyme hydrolysis, ethanol fermentation, value-added chemicals, inhibitors

\section{INTRODUCTION}

The high resistance of cellulose to degradation is the main biological barrier to lignocellulosic processing on a large scale (Ximenes et al., 2021). To overcome that, the application of mild and ecofriendly pretreatment techniques have been preferred instead of traditional acid or alkali pretreatments that have been previously proposed for lignocelluloses. Compared to the latter two pretreatments, hydrothermal pretreatment can be performed in a large scale under more gentle conditions (Pedersen and Meyer, 2010; Ruiz et al., 2020).

Liquid hot water (LHW) and to a lesser extent ozonolysis have been tested for the pretreatment of different lignocellulosic materials with LHW pretreatment being one of the leading pretreatments 
since it improves cellulose digestibility at lower cost, and is carried out once without chemicals (Kim et al., 2009; Kim et al., 2011; Kim et al., 2013; Ximenes et al., 2017; Ruiz et al., 2020; 2021). When choosing operational conditions of pretreatment, it is important to consider the type of biomass as well as the formed lignocellulosic degradation products that are inhibitory to downstream biochemical reactions (Ko et al., 2015a,b,c; Jonsson and Martin, 2016, Ximenes et al., 2017; Ruiz et al., 2021). In this sense, LHW pretreatment of a variety of lignocellulosic materials has included a wide range of operational conditions, including temperature, resident time, particle size, and water-to-solid biomass ratio, among others, and aims to avoid the formation of enzyme and/or microbial inhibitors. Hydrothermal pretreatment is generally performed under conditions of $150-230^{\circ} \mathrm{C}$ for $10-50 \mathrm{~min}$ and pressures corresponding to about 4.9-20 bars (Kim et al., 2009; Rasmussen et al., 2014; Ximenes et al., 2017; Aguilar et al., 2018; Pino et al., 2018; Ruiz et al., 2021). Hydronium ions act as catalysts to hydrolyze and solubilize hemicellulose at an elevated temperature, while acetic acid and other organic acids generated from hemicellulose also facilitate this process (Weil et al., 1998; Kim I. J. et al., 2014; Kim Y. et al., 2014; Ximenes et al., 2017; Ruiz et al., 2020).

Ozonolysis is a less studied pretreatment than LHW and represents another promising approach for lignocellulosic treatment since it has a high specificity of reaction with ozone gas being readily obtained at atmospheric pressure and room temperature. Other benefits are moderate cost of production and no wastewater generation (Barros et al., 2013; Gitifar et al., 2013; Panneerselvam et al., 2013; Travaini et al., 2013; Perrone et al., 2016).

Combined pretreatments of lignocellulosic substrates have recently been proposed for different types of biomass aiming at a more effective result when individual features of the two pretreatments are combined. A more effective recovery of lignin and hemicellulose is possible with the potential of maximizing their application in a biorefinery concept (Sun et al., 2016). The estimated global production of bio-based chemicals and polymers is about 50 million metric tonnes per year (mtpy), but most chemicals and polymers are still produced from petroleum sources (Jong et al., 2012; Rosales-Calderon and Arantes, 2019).

Lignocellulosic materials consist of $\sim 30 \%$ lignin by weight and $40 \%$ by energy (Perlack et al., 2005; Beauchet et al., 2012). In this sense, lignin is a valuable resource that merits further study to increase the commercial viability of a biorefinery (Agrawal et al., 2014), although technologies aiming to convert lignin to macromolecules and aromatic chemicals are still under development (Rosales-Calderon and Arantes, 2019). Potential uses of lignin-derived products already include production of activated carbon, binders, carbon fibers, motor fuel, plastic materials, and sorbents (Demuner et al., 2019). The combination of ozonolysis and LHW pretreatments tested here to enhance enzymatic hydrolysis, and alleviate inhibition during saccharification and fermentation of sugarcane bagasse (SCB) is also attractive for generating valued compounds from phenolic compounds derived from lignin.

\section{MATERIAL AND METHODS}

\section{Material}

SCB from 2013/2014 period of harvesting was supplied by Alta Mogiana sugarcane mill (São Joaquim da Barra, Brazil). The experimental work was developed between 2015 and 2017. The biomass was washed six times with deionized (DI) water, dried in an oven at $45^{\circ} \mathrm{C}$ to $10 \%$ or lower humidity, and milled to a particle size of about $1.0 \mathrm{~mm}$ before use. Enzymatic cocktails Cellic ${ }^{\mathrm{TM}}$ CTec $2^{\circledR}$ and $\mathrm{HTec} 2{ }^{\circledR}$ were provided by Novozymes Latin America (Araucária, Brazil). All other reagents and chemicals, unless otherwise noted, were purchased from Sigma-Aldrich (St. Louis, MO, United States). The fermentative industrial strain (Saccharomyces cerevisiae JP1) was provided by AEB Latin America (Sao José dos Pinhais, Brazil).

\section{Pretreatments of Biomass}

Two types of pretreatments were evaluated individually and/or in a combined sequence. Ozonolysis was performed using $\mathrm{O}_{3}$ gas to chemically oxidize biomass components, and LHW was employed as a physical process using water as the reagent. Combined ozonolysis was performed first to degrade lignin, and then followed by LHW. Operational conditions of each one are described.

\section{Ozonolysis}

Ozonolysis was performed at room temperature and atmospheric pressure, according to Travaini et al. (2013), with few modifications. In total, $25.0 \mathrm{~g}$ of dry SCB were humidified at $50 \%(\mathrm{w} / \mathrm{v})$ with DI water, filled in a fixed bed glass column $(2.7 \times 50.0 \mathrm{~cm})$, and kept under saturated gas $\mathrm{O}_{3}$ (flux of $32.0 \mathrm{mg} \mathrm{min}^{-1}$ ) for $60 \mathrm{~min}$. Ozone was produced from atmospheric air by the corona process (Radast 10C, OzoxiOzonio). Ozone flux was monitored according to the Standard Methods for the Examination of Water and Wastewater (APHA, 1998). After pretreatment, SCB was air-dried at room temperature prior to cold water washing, performed by a five-step sequential procedure. Each step was carried out mixing $5.0 \%(\mathrm{w} / \mathrm{v})$ of pretreated SCB with DI water under $30 \mathrm{~min}$ of agitation at room temperature, followed by filtration to separate washed solids, which were dried at $45^{\circ} \mathrm{C}$ for $24 \mathrm{~h}$ before enzymatic hydrolysis. The supernatants of each washing were stored at $4^{\circ} \mathrm{C}$ protected from light until analysis of total phenolics.

\section{Liquid Hot Water}

LHW pretreatment was conducted as described previously (Kim et al., 2009; Ko et al., 2015a) with few modifications. Each batch was performed by mixing $3.5 \mathrm{~g}$ of dry SCB (untreated or ozonized SCB) with DI water for a final concentration of $10 \%$ solids $(w / v)$. The resulting material was placed in a metal column $(2.2 \times$ $13.5 \mathrm{~cm}$ ) for heating in a sand bath at $190^{\circ} \mathrm{C}$ for $15 \mathrm{~min}$. It was heated for $5 \mathrm{~min}$. The tube was quenched in water for $20 \mathrm{~s}$ and then placed in an ice bucket for $25 \mathrm{~min}$ to stop the reaction. The pretreated material was then vacuum filtered using Whatman ${ }^{\circledR}$ no 1 filter paper to separate the solids from liquor (suspension). 
Same five washing steps at room temperature described before were performed in the LHW-pretreated solids. The liquor from pretreatment and supernatants of each washing were stored at $4^{\circ} \mathrm{C}$ protected from light until analysis of total phenolics.

\section{Enzymatic Hydrolysis}

Hydrolysis experiments were conducted using 10\% (w/v) of pretreated SCB as a substrate. SCB was suspended in $0.05 \mathrm{M}$ sodium citrate buffer at $\mathrm{pH}$ 5.0. The reaction was conducted in an incubator at $50^{\circ} \mathrm{C}$ and $150 \mathrm{rpm}$, using a $4: 1$ mixture of Cellic CTec2 and HTec2 (180 FPU mL ${ }^{-1}$ FPase activity; 13,213 $\mathrm{UI} \mathrm{mL}^{-1}$

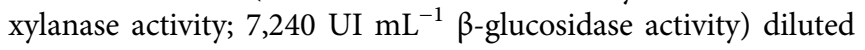
into two enzyme loadings. Loadings were calculated based on the chemical characterization of samples, that is, 9.1 and $17.5 \mathrm{mg}$ protein $\mathrm{g}^{-1}$ of glucan. At $96 \mathrm{~h}$ of hydrolysis, aliquots from supernatant were taken every $24 \mathrm{~h}$ in duplicate and analyzed for soluble carbohydrates, reported here as an average with an indicated standard deviation. The final volume of hydrolyzate from each replicate unit was recovered after the separation from solid residues by centrifugation $(12,096 \times \mathrm{g}, 10 \mathrm{~min})$, combined in a single unit, corresponding to individual pretreatments, and kept frozen until the fermentative step.

\section{Alcoholic Fermentation}

The fermentability of selected hydrolyzate obtained after the hydrolysis of double-pretreated SCB was tested using two Saccharomyces cerevisiae strains. The first (JP1) is an industrial strain selected by its roughness and adaptability to perform alcoholic fermentation under adverse conditions in the firstgeneration production of ethanol, which is also already in use in Brazilian mills. The second yeast, Y150, is a strain obtained by the adaptative laboratory evolution method following similar protocol described by Vasconcellos et al. (2019). Yeast reactivation was made by pre-cultivation of freeze-stored cells in the YEPD medium $\left(10 \mathrm{~g} \mathrm{~L}^{-1}\right.$ yeast extract; $10 \mathrm{~g} \mathrm{~L}^{-1}$ peptone; $20 \mathrm{gL}^{-1}$ glucose) in an incubator at $28^{\circ} \mathrm{C}, 200 \mathrm{rpm}$, and $24 \mathrm{~h}$ prior use.

Three hydrolyzates were obtained from each pretreated material (ozonolysis; LHW; and combined ozonolysis + LHW, respectively) as substrates for alcoholic fermentations. Substrates were sterilized by vacuum filtering through a $0.22-\mu \mathrm{m}$ membrane, and $0.5 \mathrm{~g}$ fresh cells was added per liter as inoculum. The inoculum standardization was carried out through measuring the cell density of precultured suspension in a colorimeter, followed by two steps of centrifugation $(12,096 \times \mathrm{g}, 10 \mathrm{~min})$, washing and resuspension in sterilized DI water. The washed cells were inoculated in $40 \mathrm{ml}$ of each hydrolyzate substrate. The fermentation experiments were carried out in an incubator at $32^{\circ} \mathrm{C}$ and $150 \mathrm{rpm}$ in duplicate at a semi-anaerobic condition. The concentration of cells, ethanol production, and glucose consumption were systematically monitored by sampling at $6,12,20,24,30$, and $40 \mathrm{~h}$ of fermentation, respectively. Glucose to ethanol conversion yields (\%) were calculated at the endpoint of each fermentation experiment by assuming: $\left[\left(\mathrm{gL}^{-1}\right.\right.$ of ethanol produced $) /\left(\mathrm{gL}^{-1}\right.$ of initial glucose *0.511)]* 100 .

\section{Analytical Methods}

The chemical composition of SCB was determined according to LAP-010-determination of extractives in biomass (Sluiter et al., 2012) and the LAP for the determination of structural carbohydrates and lignin in biomass (Sluiter et al., 2012). Glucose and ethanol concentrations were measured by HPLC analysis as described previously (Cao et al., 2013) using an Aminex HPX-87H ion exchange column $(300 \times 7.8 \mathrm{~mm}$, BioRad Laboratories Inc., Hercules, CA). The column was connected with a Milton Roy mini pump (Milton Roy Co., Ivyland, PA), a Waters $^{\mathrm{TM}} 717$ plus autosampler, and a Waters ${ }^{\mathrm{TM}} 2,414$ refractive index detector (Waters Corp., Milford, MA). The procedure for total phenolic analyses was adapted from the study by Singleton et al. (1999) to a micro-scale analysis using Folin-Ciocalteau reagent.

The results were expressed in milligrams per liter $\left(\mathrm{mg} \mathrm{L}^{-1}\right)$ of gallic acid equivalent (GAE). The protein content of commercial enzymes used in hydrolysis assays was determined using the Pierce BCA Protein Assay Kit (Thermo Scientific, Rockford, IL). Filter paper activity was measured according to Mandels et al. (1976). Cell concentration was estimated by optical density in a spectrophotometer at $630 \mathrm{~nm}$, using 1:10 dilution with sterile DI water, in comparison to the dry weight curve of cellular growth, previously determined to JP1 strain.

Infrared spectroscopy data (FTIR-ATR) were collected using a Perkin Elmer FTIR Spectrum Two. Both FTIR-ATR and powder $\mathrm{X}$-ray diffraction (XRD) patterns of SCB were obtained on a Model 300 miniFlex Rigaku ${ }^{\circledR}$ diffractometer according to Perrone et al. (2016). The crystallinity index was calculated by the method proposed by Segal et al. (1959).

Scanning electron microscopy (SEM) was carried out using a FEI Quanta 200 scanning electron microscope (FEI Company, Eindhoven, Netherlands) with an accelerating voltage of $12.5 \mathrm{kV}$. Sample preparation comprised 1) mixing bagasse in $2.5 \%(\mathrm{v} / \mathrm{v})$ glutaraldehyde in $0.1 \mathrm{M}$ phosphate buffer $(\mathrm{pH} 7.3)$ for $48 \mathrm{~h}$ at room temperature; and 2) washing the sample in distilled water and after fixing it in $1 \%(\mathrm{v} / \mathrm{v})$ osmium tetroxide diluted in distilled water for $30 \mathrm{~min}$ at room temperature. Bagasse was dehydrated by a series of ethanol washes and then critical point-dried with $\mathrm{CO}_{2}$, and sputter-coated with gold (Bal-Tec SCD 050) (Perrone et al., 2016).

\section{RESULTS AND DISCUSSION}

\section{Chemical Characterization of Pretreated Sugarcane Bagasse}

Three different samples of pretreated SCB were obtained from individual ozonolysis and LHW pretreatments or a combination. Chemical characterization shows that ozonolysis and LHW have distinct effects on SCB, as summarized in Table 1. Ozone acted mostly on delignification, causing about $37 \%$ reduction of acid insoluble lignin (AIL) and partially decreasing the hemicellulose portion (components determined as xylose, arabinose, and acetyl groups) as a secondary effect (20\% solubilization). Delignification by ozonolysis was relevant to overcome the recalcitrant character of lignin through its separation and the breakdown of lignin 
TABLE 1 | Compositional analysis of sugarcane bagasse generated by different pretreatment approaches and the untreated sample. Solid composition is presented as dry weight on a free extractive basis (\%).

\begin{tabular}{|c|c|c|c|c|}
\hline \multirow[t]{2}{*}{ Component } & \multicolumn{4}{|c|}{ Composition of sugarcane bagasse (\%) } \\
\hline & Untreated & $\begin{array}{c}\text { Liquid } \\
\text { hot water pretreated }\end{array}$ & Ozonolysis pretreated & $\begin{array}{l}\text { Ozonolysis + liquid } \\
\text { hot water pretreated }\end{array}$ \\
\hline Cellulose & $45.9 \pm 0.10$ & $53.6 \pm 0.49$ & $61.2 \pm 1.64$ & $80.5 \pm 1.44$ \\
\hline Hemicellulose & 24.5 & 19.1 & 19.5 & 4.1 \\
\hline Xylan & $20.2 \pm 0.59$ & $17.5 \pm 0.17$ & $18.6 \pm 0.53$ & $4.1 \pm 0.11$ \\
\hline Arabinose & $2.6 \pm 0.11$ & $1.5 \pm 0.07$ & $1.0 \pm 0.05$ & 0.0 \\
\hline Acetyl group & $1.7 \pm 0.15$ & 0.0 & 0.0 & 0.0 \\
\hline Lignin & 26.9 & 25.1 & 18.0 & 14.1 \\
\hline Acid-insoluble lignin & $22.9 \pm 0.36$ & $21.8 \pm 0.04$ & $14.3 \pm 0.30$ & $12.5 \pm 0.27$ \\
\hline Acid-soluble lignin & $4.0 \pm 0.29$ & $3.3 \pm 0.01$ & $3.7 \pm 0.08$ & $1.7 \pm 0.03$ \\
\hline Ashes & $0.5 \pm 0.12$ & $0.9 \pm 0.06$ & $1.1 \pm 0.32$ & $1.3 \pm 0.27$ \\
\hline Total & 97.8 & 98.7 & 99.8 & 100.1 \\
\hline
\end{tabular}

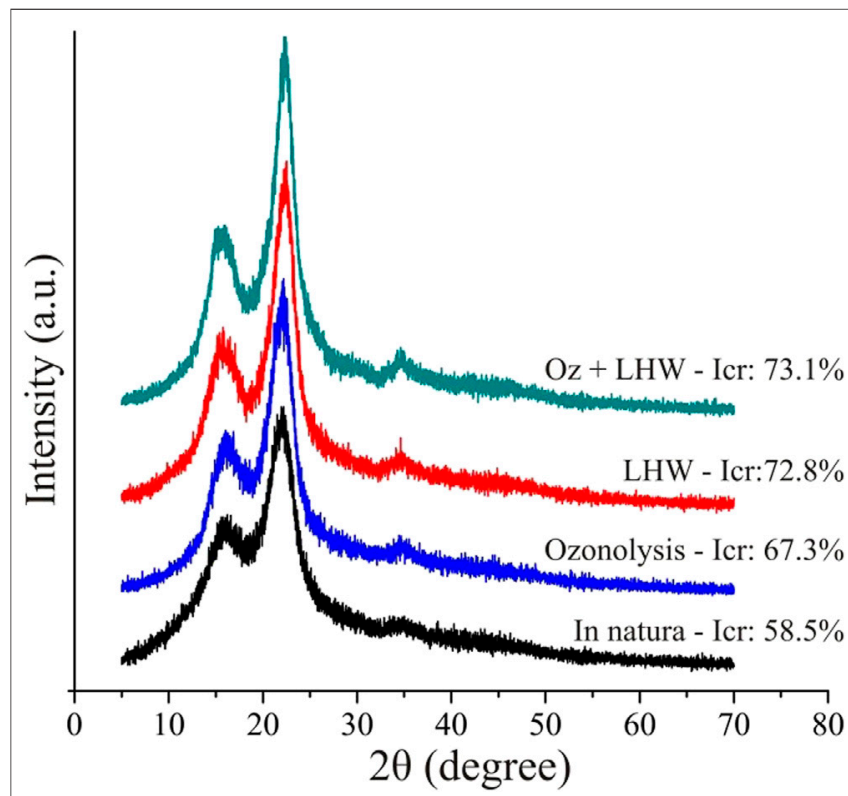

FIGURE 1 |XRD patterns and the corresponding results of crystallinity index (Icr) for in nature sugarcane bagasse, ozonolysis, LHW, and ozonolysis + LHW pretreatments.

(Santos et al., 2019; Ázar et al., 2019). It also generated a rich fraction of phenolics and other compounds with potential use in green chemistry bioconversions, while also removing their enzyme and the microbial potential inhibitory effect in subsequent steps of enzyme hydrolysis and microbial fermentation (Kim et al., 2011, 2016; Ximenes et al., 2011; Michelin et al., 2016). Although the individual LHW pretreatment reduced the hemicellulose content $(22 \%$ of solubilization), it had little effect on lignin (about 5\% reduction of AIL).

The double-pretreated SCB (ozonolysis and LHW combined) generated the highest cellulose $(80.5 \%)$ and the lowest hemicellulose $(4.1 \%)$ contents among all samples, indicating an intensive solubilization (up to $80 \%$ ) of hemicellulose into

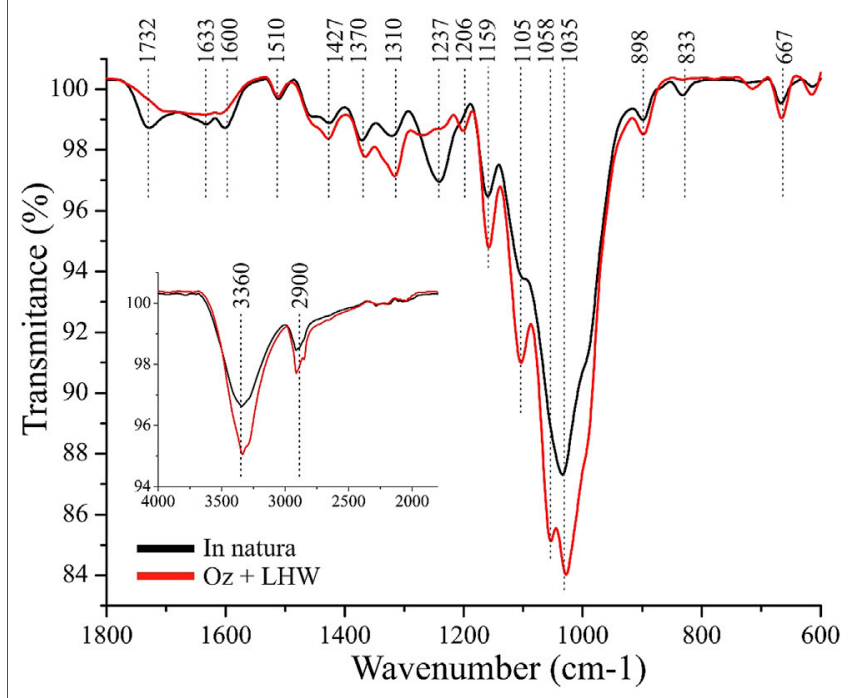

FIGURE 2 | FTIR-ATR spectra in natural and ozonolysis + LHW sugarcane bagasse samples.

liquor and reaching a maximal delignification rate $(45 \%$ reduction of AIL). In that sense, even taking into consideration all the pretreatments increased the glucan availability, its availability in the ozone + LHW-pretreated biomass was 75,50 , and $32 \%$ higher than that of the initial content (comparing only untreated LHW and ozone-pretreated SCB), respectively. The action on the lignin barrier observed in double-pretreated SCB helps to reduce enzyme adsorption on lignin and increase the accessibility of cellulose to enzyme (Zanchetta et al., 2018), which can also lead to a reduction of enzyme loading and cost.

We observed an increase of the crystallinity index (CrI) according to the intensity of pretreatments in the following order: untreated < ozonolysis < LHW $<\mathrm{Oz}+\mathrm{LHW}$ (Figure 1). We observed the highest CrI (73.1\%) in the most intensive pretreatment (combined ozonolysis + LHW), possibly associated with lignin and hemicellulose degradation. In agreement with that reported in the literature (Gabhane et al., 


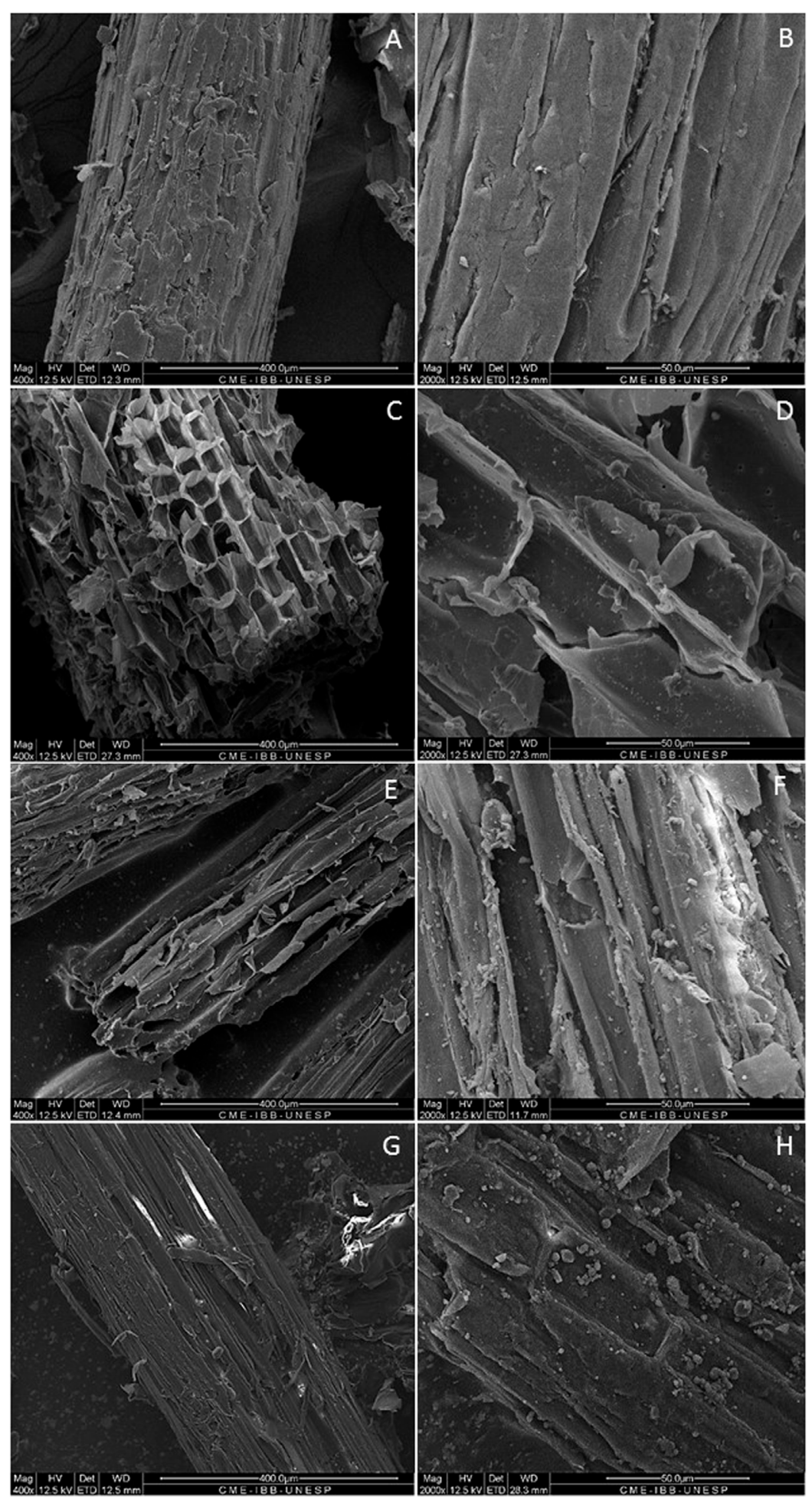

FIGURE 3 | Scanning electron microscopy of untreated bagasse (A,B), ozone-treated bagasse (C,D), LHW-treated bagasse (E,F), and combined pretreatment ozone + LHW (G,H).

2015; Pereira et al., 2016; Perrone et al., 2016), it seems that the increase in CrI observed here is more a function of removal of non-crystalline components from the biomass.

\section{FTIR Analysis}

Infrared spectrometry (FTIR-ATR) was used to analyze changes in functional groups that compose the fibers of SCB after 
pretreatment, indicating possible targets of reaction in the material (Figure 2). A pronounced reduction in the intensity of infrared absorption bands found at $1,732 \mathrm{~cm}^{-1}$ and $1,237 \mathrm{~cm}^{-1}$ in the pretreated sample confirmed the strong removal of hemicellulose (Liu et al., 2007), which is also detected by compositional characterization analysis (Table 1). The increase of the cellulose content is also shown by FTIR-ATR, especially by the increase of infrared absorption bands at $1,427 \mathrm{~cm}^{-1}$ and $1,370 \mathrm{~cm}^{-1}$ (assigned to the crystalline cellulose structure), and amorphous cellulose at $898 \mathrm{~cm}^{-1}$ (Pereira et al., 2016).

A decrease in the lignin content in the double-pretreated sample was observed based on the presence of bands related to functional groups or specific lignin linkages, such as aromatic rings at $1,600 \mathrm{~cm}^{-1}$ and $1,510 \mathrm{~cm}^{-1}$ (Pereira et al., 2016), and carbonyl groups conjugated with aromatic rings at $1,633 \mathrm{~cm}^{-1}$ (Zhou et al., 2016). Also, the band at $833 \mathrm{~cm}^{-1}$ is associated to [C$\mathrm{H}$ ] vibrations out of a plane in $p$-hydroxyphenyl units (Hoareau et al., 2004). The presence of these bands indicates a clear decrease of the intensities in the spectra corresponding to the combined pretreatments, which is again in agreement with the large extent of lignin removal (compositional characterization, Table 1).

\section{Ultrastructural Changes in Pretreated Sugarcane Bagasse}

Scanning electron microscopy (SEM) was performed to analyze possible tissue damage and ultrastructural changes on the bagasse surface after each pretreatment (ozone, LHW, and ozone + LHW) in comparison to the untreated sample (Figures 3A,B). The initial smooth and intact structure of fibers was strongly affected by both ozone and hot water pretreatments (Figures 3C-F). Cell walls were ruptured by the ozone gas, generating opened cells with increased porosity and surface area (Figures 3C,D). Similar effects were observed with hot water. A cracked surface characterized by holes formed in the cell wall is noted; the holes may be caused by the high pressure experienced during LHW processing (Figures 3E,F).

A disorganized structure with greater exposure of fibers was also present in $\mathrm{SCB}$ pretreated with $\mathrm{SO}_{2}$ and $\mathrm{CO}_{2}$ steam (Corrales et al., 2012). The presence of globular structures on the surface of samples exposed to high temperature is probably related to the formation and accumulation of globular lignin at $190^{\circ} \mathrm{C}$. It is known that lignin softens and agglomerates at a relatively low temperature $\left(<200^{\circ} \mathrm{C}\right)$ (Hamdan et al., 2000; Zhang et al., 2015). All these observations also apply to the double-pretreated sample, which showed a random breaking along the fibers, and a total collapse of the cellular structure due to the combined process (Figures 3G,H). These morphological changes of SCB obtained after combined pretreatment enhance the accessibility of cellulose-degrading enzymes and facilitate the hydrolysis of cellulose.

\section{Effect of Pretreatments on Phenolic Compound Releasing}

When LHW pretreatment alone was performed, $1,462 \mathrm{mg} \mathrm{L}^{-1}$ of phenolics were solubilized through liquor, and $857 \mathrm{mg} \mathrm{L}^{-1}$ remained on solids, reaching a total of $2,320 \mathrm{mg} \mathrm{L}^{-1}$ of released phenolics. The lowest concentration was observed when ozonolysis was performed as a single pretreatment. Here, $936 \mathrm{mg} \mathrm{L}^{-1}$ of total phenolic compounds were released. Although delignification is stronger in ozonolysis than in LHW pretreatment, as previously demonstrated by biomass compositional and FTIR-ART analysis, the lower release of phenols may be explained by the conversion of acid-insoluble lignin (AIL) preferentially into acids with low molecular weight, such as formic, acetic, oxalic, and carboxylic acids (Travaini et al., 2016). This hypothesis is further supported by the intense acidification of the ozonized solids, which regularly had a $\mathrm{pH}$ near to 2.0 after ozonolysis. The highest concentration of total phenolics released was almost $3,000 \mathrm{mg} \mathrm{L}^{-1}$ when combining ozonolysis and LHW pretreatments, with $2,300 \mathrm{mg}^{-1}$ solubilized in the liquor and $681 \mathrm{mg} \mathrm{L}^{-1}$ remaining in solids. Thus, the use of this combined pretreatment approach resulted in a maximal release of phenolic compounds.

\section{Effect of Phenolic Compound Removal on 96-h Enzymatic Hydrolysis}

The low molecular weight phenolic compounds derived from lignin depolymerization had a negative impact on enzyme performance, possibly due to both non-productive adsorption and inhibitory effects during saccharification and microbial fermentation (Ximenes et al., 2010; Nakagame et al., 2011; Ximenes et al., 2011; Jönsson and Martín, 2016). Therefore, phenolic compounds must be removed from pretreated solids prior to enzymatic hydrolysis to enhance the yields of both the saccharification and the fermentation steps (Kim et al., 2013; Xiros and Olsson, 2014).

Sequential washing of the material at room temperature (see Material and Methods section 2.2.1, section 2.2.2) significantly reduced phenolics embedded in the pretreated fibers (Figure 3 ). A maximum of $33 \mathrm{gL}^{-1}$ of glucose was reached in $24 \mathrm{~h}$ during hydrolysis of washed ozone-pretreated SCB (Figure 4A), which represented a conversion of about $75 \%$ of cellulose into glucose vs. $44 \%$ for the enzymatic hydrolysis of the non-washed pretreated sample. Similarly, high cellulose conversion was observed for washed LHW-pretreated SCB samples (Figure 4B), although lower yields were obtained than washed ozone-pretreated samples (compare Figures 4A,B). This suggests better accessibility of substrate to enzyme hydrolysis in the ozonepretreated sample and the presence of more enzyme inhibitors, including remaining phenolic compounds in the LHWpretreated samples, or both.

\section{Kinetics of Enzymatic Hydrolysis of Pretreated Sugarcane Bagasse}

A kinetic study was performed using reduced enzyme loading (9 $\mathrm{mg}$ of total protein per gram of glucan) for hydrolysis of untreated and pretreated SCB under different conditions for $96 \mathrm{~h}$. The double pretreated SCB was also tested under non- and washed conditions. 


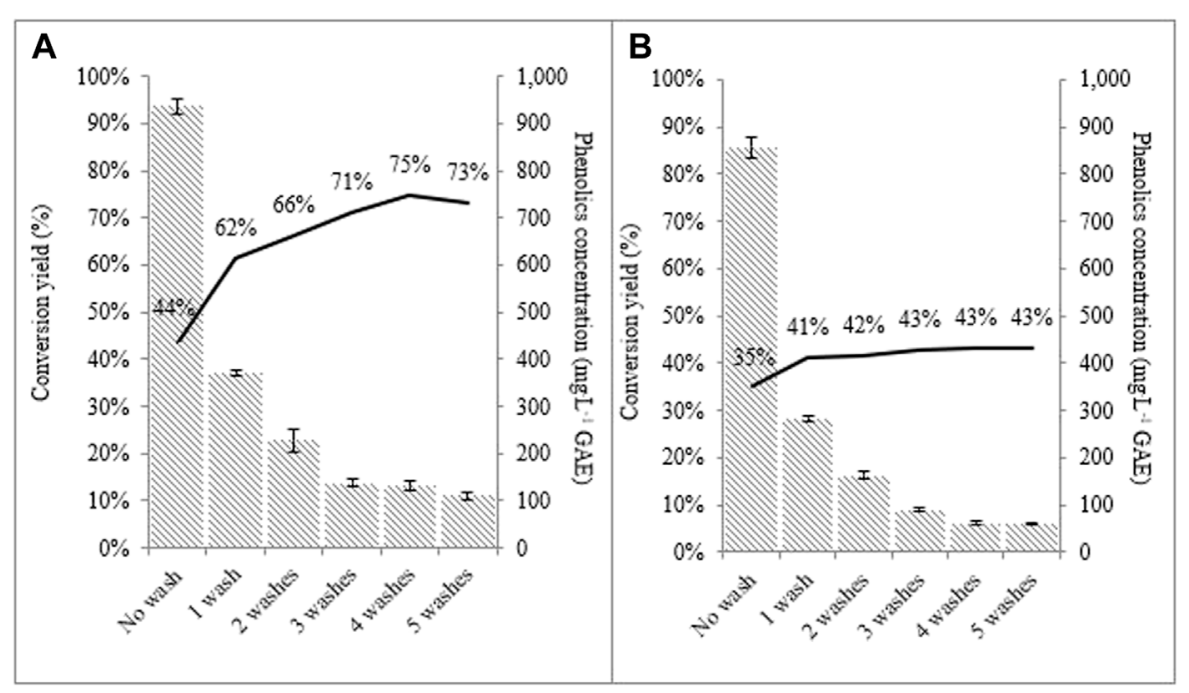

FIGURE 4 | Concentration of phenolic compounds (bars) and cellulose conversion yield (lines) in enzymatic hydrolysis (17.5 mg protein $\times \mathrm{g}^{-1} \mathrm{glucan}$; $10 \%$ total solids loading, $96 \mathrm{~h}$ ) related to sequential room temperature washes. (A) ozone-pretreated sugarcane bagasse; (B) LHW-pretreated sugarcane bagasse.
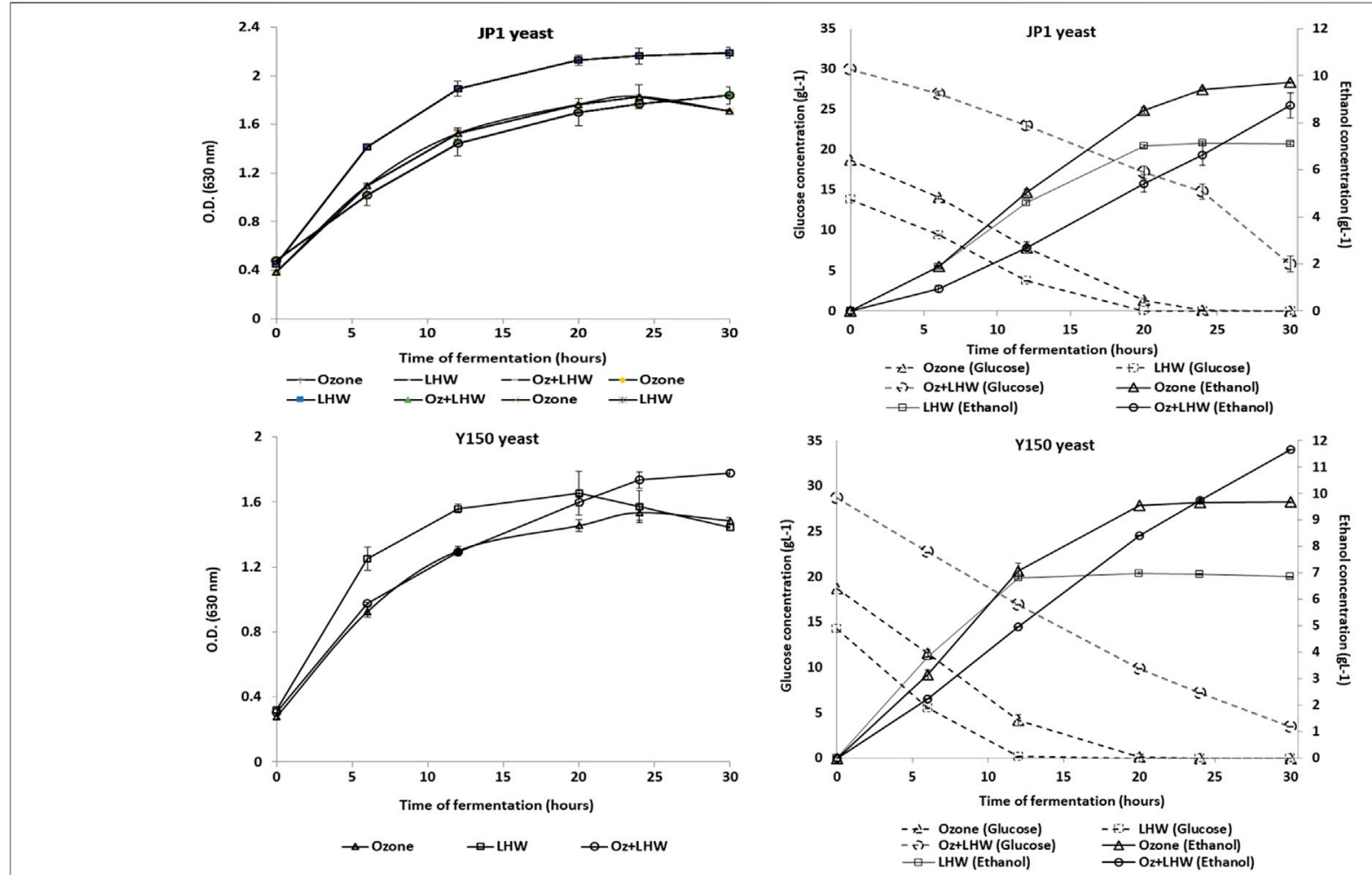

FIGURE 5 | Kinetics of yeasts JP1 and Y150 in alcoholic fermentation of sugarcane bagasse hydrolysate pretreated by individual and combined Ozonolysis and LHW approaches.

The kinetics of hydrolysis of different SCB samples showed that the yield increase was consistent with the increase of the cellulose content after pretreatment and washes, relative to the decline of hemicellulose removal (in LWH-pretreated bagasse), or lignin reduction (in ozone-pretreated bagasse), or associated to both effects (in combined pretreatments). For the combined pretreatments, $43.0 \mathrm{~g} \mathrm{~L}^{-1}$ of glucose was generated after enzymatic hydrolysis of double-pretreated SCB, corresponding 
to $59 \%$ of conversion from initial glucan vs. $20,47,37$, and $10 \%$ for untreated, ozone, LHW, and double pretreated samples, respectively. The hydrolyzate from double pretreated samples was tested by fermentation experiments that are reported and discussed in the next section. A strong inhibitory effect of pretreatment by-products was observed over cellulolytic and hemicellulolytic enzymes when the hydrolysis was performed in the presence of liquor derived from combined pretreatment, reducing cellulose conversion to about $10 \%$, probably due to potential enzyme inhibitors mentioned before (Ximenes et al., 2010, 2011; Kim et al., 2011; Gabhane et al., 2015).

\section{Alcoholic Fermentation of Hydrolyzate}

JP1 and Y150 yeast strains were able to ferment the selected hydrolyzate without nutrient supplementation, with all glucose available exhausted after $42 \mathrm{~h}$ (Figure 5), while xylose concentration remained constant. This latter result was expected since these yeast strains cannot ferment xylose to ethanol. The final yield of glucose to ethanol was similar for both strains, $87 \%$ for JP1 vs. $92 \%$ for Y150 (Figure 5). However, Y150 strain was faster on the fermentation (conversion yield of $67 \%$ for Y150 after $24 \mathrm{~h}$ vs. $43 \%$ for JP1), indicating some possible adaptation advantage to the microbial inhibitory compounds still present in the hydrolyzate, including phenolics (Larsson et al., 2000; Palmqvist and Hahn-Hägerdal, 2000a, 2000b). Since the cellular density in all replicates of fermentations was similar, Y150 cells were found to be more efficient on ethanol production.

\section{CONCLUSIONS}

The effects of ozonolysis and LHW sugarcane bagasse pretreatment were observed in individual and combined pretreatment processes that resulted in a new approach for achieving a high amount of cellulose for hydrolysis purposes while generating an acid liquor fraction rich in sugars and phenolic compounds. The double pretreatment removed enzyme and microbial inhibitors, and generated water-soluble products that can be explored in green chemistry bioconversions processes. The combined ozonolysis and LHW pretreatment also generated, after enzyme hydrolysis, a hydrolyzate rapidly fermented by $S$. cerevisiae without the need for detoxification steps or nutrient supplementation. The maximal conversion yield by strain Y150 in fermenting glucose to ethanol was $92 \%$ in $42 \mathrm{~h}$. This approach and results obtained are in agreement with a proposed model of the lignocellulosic biorefinery (Silva et al.,

\section{REFERENCES}

Agrawal, A., Kaushik, N., and Biswas, S. (2014). Derivatives and Applications of Lignin - an Insight. Scitech. J. 1, 30-36.

Aguilar, D. L., Rodríguez-Jasso, R. M., Zanuso, E., Lara-Flores, A. A., Aguilar, C. N., Sanchez, A., et al. (2018). "Operational Strategies for Enzymatic Hydrolysis in a Biorefinery," in Biorefining Biomass to Biofuels-Opportunities and Perception. Editors S. Kumar and R. Sani (Cham: Springer), 223-248. doi:10.1007/978-3-319-67678-4_10 APHA (1998). Standard Methods for the Examination of Water and Wastewater. Washington: American Public Health Association, 202-242.
2018), in which sugars from cellulose and hemicellulose are used to generate biofuels and bioproducts, while lignin components are utilized in the synthesis of other bioproducts and act as an alternative heat and energy source.

\section{DATA AVAILABILITY STATEMENT}

The original contributions presented in the study are included in the article/Supplementary Material, further inquiries can be directed to the corresponding author.

\section{AUTHOR CONTRIBUTIONS}

SB: experimental design, performance and manuscript writing; EX: experimental design, manuscript writing, review, and formatting; OP: experimental design, performance, and manuscript writing; CC: experimental design and performance; DK: experimental design and performance; MB: experimental design and manuscript writing; EG: experimental design and manuscript writing; EF: manuscript writing, review, and formatting; RS: experimental design and manuscript writing; ML: experimental design, manuscript writing, and review.

\section{ACKNOWLEDGMENTS}

We acknowledge support from the United States Department of Energy Bioenergy Technologies Office (DOE-BETO) under the contract number DEEE0008256. We also thank the companies Usina Alta Mogiana, AEB Latin America, and Novozymes Latin America for the donation of materials; to the Brazilian government for financial support through the Coordination for the Improvement of Higher Education Personnel (CAPES Print program, process 88887.364337/2019-00) and "Ciência Sem Fronteiras" scholarship) and the Brazilian National Council for Scientific and Technological Development (CNPq); to FAPESP for supporting projects 2008/58077-0, 2010/12624-0, 2014/ 02080-4; to INCT-Bioetanol, Electron Microscopy Center of the Biosciences Institute (Unesp, Botucatu-SP, Brazil); to undergraduate students Márcio Justi Laranja (Unesp, São José do Rio Preto-SP, Brazil) and Haley Roos (Purdue University, West Lafayette-IN, United States) for their contribution in preparing samples and performing previous analytical assays; and to Xingya Liu for her technical support.

Ázar, R. I. S. L., Morgan, T., Barbosa, M. H. P., Guimarães, V. M., Ximenes, E., and Ladisch, M. (2019). Impact of Protein Blocking on Enzymatic Saccharification of Bagasse from Sugarcane Clones. Biotechnol. Bioeng. 116 (7), 1584-1593. doi:10.1002/bit.26962

Barros, R. d. R. O. d., Paredes, R. d. S., Endo, T., Bon, E. P. d. S., and Lee, S.-H. (2013). Association of Wet Disk Milling and Ozonolysis as Pretreatment for Enzymatic Saccharification of Sugarcane Bagasse and Straw. Bioresour. Tech. 136, 288-294. doi:10.1016/j.biortech.2013.03.009

Beauchet, R., Monteil-Rivera, F., and Lavoie, J. M. (2012). Conversion of Lignin to Aromatic-Based Chemicals (L-Chems) and Biofuels (L-Fuels). Bioresour. Tech. 121, 328-334. doi:10.1016/j.biortech.2012.06.061 
Cao, G., Ximenes, E., Nichols, N. N., Zhang, L., and Ladisch, M. (2013). Biological Abatement of Cellulase Inhibitors. Bioresour. Tech. 146, 604-610. doi:10.1016/j. biortech.2013.07.112

Corrales, R. C. N. R., Mendes, F. M. T., Perrone, C. C., Sant'Anna, C., de Souza, W., Abud, Y., et al. (2012). Structural Evaluation of Sugar Cane Bagasse Steam Pretreated in the Presence of CO2 and SO2. Biotechnol. Biofuels 5, 36. doi:10. 1186/1754-6834-5-36

Demuner, I. F., Colodette, J. L., Demuner, A. J., and Jardim, C. M. (2019). Biorefinery Review: Wide-Reaching Products through Kraft Lignin. BioRes. 14, 7543-7581. doi:10.15376/biores.14.3.demuner

dos Santos, A. C., Ximenes, E., Kim, Y., and Ladisch, M. R. (2019). Lignin-Enzyme Interactions in the Hydrolysis of Lignocellulosic Biomass. Trends Biotechnol. 37, 518-531. doi:10.1016/j.tibtech.2018.10.010

Gabhane, J., William, S. P. M. P., Vaidya, A. N., Das, S., and Wate, S. R. (2015). Solar Assisted Alkali Pretreatment of Garden Biomass: Effects on Lignocellulose Degradation, Enzymatic Hydrolysis, Crystallinity and Ultra-structural Changes in Lignocellulose. Waste Manag. 40, 92-99. doi:10.1016/j.wasman.2015.03.002

Gitifar, V., Eslamloueyan, R., and Sarshar, M. (2013). Experimental Study and Neural Network Modeling of Sugarcane Bagasse Pretreatment with H2SO4 and O3 for Cellulosic Material Conversion to Sugar. Bioresour. Tech. 148, 47-52. doi:10.1016/j.biortech.2013.08.060

Hamdan, S., Dwianto, W., Morooka, T., and Norimoto, M. (2000). Softening Characteristics of Wet wood under Quasi Static Loading. Holzforschung 54, 557-560. doi:10.1515/hf.2000.094

Hoareau, W., Trindade, W. G., SiegmundCastellana, B., Castellan, A., and Frollini, E. (2004). Sugar Cane Bagasse and Curaua Lignins Oxidized by Chlorine Dioxide and Reacted with Furfuryl Alcohol: Characterization and Stability. Polym. Degrad. Stab. 86, 567-576. doi:10.1016/j.polymdegradstab.2004.07.005

Jong, E., Higson, A., Walsh, P., and Wellisch, M. (2012). Biobased Chemicals-Value Added Products from Biorefineries, 42. Wageningen, Netherlands: IEA Bioenergy Task. www.iea-bioenergy.taks42biorefineries.com.

Jönsson, L. J., and Martín, C. (2016). Pretreatment of Lignocellulose: Formation of Inhibitory By-Products and Strategies for Minimizing Their Effects. Bioresour. Tech. 199, 103-112. doi:10.1016/j.biortech.2015.10.009

Kim, D., Ximenes, E. A., Nichols, N. N., Cao, G., Frazer, S. E., and Ladisch, M. R. (2016). Maleic Acid Treatment of Biologically Detoxified Corn stover Liquor. Bioresour. Tech. 216, 437-445. doi:10.1016/j.biortech.2016.05.086

Kim, I. J., Lee, H. J., Choi, I.-G., and Kim, K. H. (2014a). Synergistic Proteins for the Enhanced Enzymatic Hydrolysis of Cellulose by Cellulase. Appl. Microbiol. Biotechnol. 98 (20), 8469-8480. doi:10.1007/s00253-014-6001-3

Kim, Y., Kreke, T., Hendrickson, R., Parenti, J., and Ladisch, M. R. (2013). Fractionation of Cellulase and Fermentation Inhibitors from Steam Pretreated Mixed Hardwood. Bioresour. Tech. 135, 30-38. doi:10.1016/j. biortech.2012.10.130

Kim, Y., Kreke, T., Mosier, N. S., and Ladisch, M. R. (2014b). Severity Factor Coefficients for Subcritical Liquid Hot Water Pretreatment of Hardwood Chips. Biotechnol. Bioeng. 111 (2), 254-263. doi:10.1002/bit.25009

Kim, Y., Mosier, N. S., and Ladisch, M. R. (2009). Enzymatic Digestion of Liquid Hot Water Pretreated Hybrid poplar. Biotechnol. Prog. 25, 340-348. doi:10. 1002/btpr.137

Kim, Y., Ximenes, E., Mosier, N. S., and Ladisch, M. R. (2011). Soluble Inhibitors/ deactivators of Cellulase Enzymes from Lignocellulosic Biomass. Enzyme Microb. Tech. 48, 408-415. doi:10.1016/j.enzmictec.2011.01.007

Ko, J. K., Kim, Y., Ximenes, E., and Ladisch, M. R. (2015a). Effect of Liquid Hot Water Pretreatment Severity on Properties of Hardwood Lignin and Enzymatic Hydrolysis of Cellulose. Biotechnol. Bioeng. 112 (2), 252-262. doi:10.1002/bit. 25349

Ko, J. K., Um, Y., Park, Y.-C., Seo, J.-H., and Kim, K. H. (2015b). Compounds Inhibiting the Bioconversion of Hydrothermally Pretreated Lignocellulose. Appl. Microbiol. Biotechnol. 99 (10), 4201-4212. doi:10.1007/s00253-0156595-0

Ko, J. K., Ximenes, E., Kim, Y., and Ladisch, M. R. (2015c). Adsorption of Enzyme onto Lignins of Liquid Hot Water Pretreated Hardwoods. Biotechnol. Bioeng. 112 (3), 447-456. doi:10.1002/bit.25359

Larsson, S., Quintana-Sáinz, A., Reimann, A., Nilvebrant, N.-O., and Jönsson, L. J. (2000). Influence of Lignocellulose-Derived Aromatic Compounds on Oxygen-
Limited Growth and Ethanolic Fermentation by Saccharomyces cerevisiae. Abab 84-86, 617-632. doi:10.1385/abab:84-86:1-9:617

Mandels, M., Andreotti, R., and Roche, C. (1976). Measurement of Saccharifying Cellulase. Biotechnol. Bioeng. Symp. 6, 21-33.

Michelin, M., Ximenes, E., de Lourdes Teixeira de Moraes Polizeli, M., and Ladisch, M. R. (2016). Effect of Phenolic Compounds from Pretreated Sugarcane Bagasse on Cellulolytic and Hemicellulolytic Activities. Bioresour. Tech. 199, 275-278. doi:10.1016/j.biortech.2015.08.120

Nakagame, S., Chandra, R. P., Kadla, J. F., and Saddler, J. N. (2011). The Isolation, Characterization and Effect of Lignin Isolated from Steam Pretreated Douglasfir on the Enzymatic Hydrolysis of Cellulose. Bioresour. Tech. 102, 4507-4517. doi:10.1016/j.biortech.2010.12.082

Palmqvist, E., and Hahn-Hägerdal, B. (2000a). Fermentation of Lignocellulosic Hydrolysates. I: Inhibition and Detoxification. Bioresour. Tech. 74, 17-24. doi:10.1016/s0960-8524(99)00160-1

Palmqvist, E., and Hahn-Hägerdal, B. (2000b). Fermentation of Lignocellulosic Hydrolysates. II: Inhibitors and Mechanisms of Inhibition. Bioresour. Tech. 74, 25-33. doi:10.1016/s0960-8524(99)00161-3

Panneerselvam, A., Sharma-Shivappa, R. R., Kolar, P., Ranney, T., and Peretti, S. (2013). Potential of Ozonolysis as a Pretreatment for Energy Grasses. Bioresour. Tech. 148, 242-248. doi:10.1016/j.biortech.2013.08.129

Pedersen, M., and Meyer, A. S. (2010). Lignocellulose Pretreatment Severity Relating pH to Biomatrix Opening. New Biotechnol. 27, 739-750. doi:10.1016/j. nbt.2010.05.003

Pereira, S. C., Maehara, L., Machado, C. M. M., and Farinas, C. S. (2016). Physicalchemical-morphological Characterization of the Whole Sugarcane Lignocellulosic Biomass Used for $2 \mathrm{G}$ Ethanol Production by Spectroscopy and Microscopy Techniques. Renew. Energ. 87, 607-617. doi:10.1016/j.renene.2015.10.054

Perlack, R. D., Wright, L. L., Turhollow, A. F., and Grahm, L. L. (2005). Biomass as Feedstock for a Bioenergy and Bioproducts Industry: The Technical Feasibility of a Billion-Ton Annual Supply. Oak Ridge, TN: U.S. Department of Energy (DOE), U.S. Department of Agriculture (USDA). http://www.osti.gov./bridge.

Perrone, O. M., Colombari, F. M., Rossi, J. S., Moretti, M. M. S., Bordignon, S. E., Nunes, C. d. C. C., et al. (2016). Ozonolysis Combined with Ultrasound as a Pretreatment of Sugarcane Bagasse: Effect on the Enzymatic Saccharification and the Physical and Chemical Characteristics of the Substrate. Bioresour. Tech. 218, 69-76. doi:10.1016/j.biortech.2016.06.072

Pino, M. S., Rodríguez-Jasso, R. M., Michelin, M., Flores-Gallegos, A. C., MoralesRodriguez, R., Teixeira, J. A., et al. (2018). Bioreactor Design for Enzymatic Hydrolysis of Biomass under the Biorefinery Concept. Chem. Eng. J. 347, 119-136. doi:10.1016/j.cej.2018.04.057

Rasmussen, H., Sørensen, H. R., and Meyer, A. S. (2014). Formation of Degradation Compounds from Lignocellulosic Biomass in the Biorefinery: Sugar Reaction Mechanisms. Carbohydr. Res. 385, 45-57. doi:10.1016/j. carres.2013.08.029

Rosales-Calderon, O., and Arantes, V. (2019). A Review on Commercial-Scale High-Value Products that Can Be Produced Alongside Cellulosic Ethanol. Biotechnol. Biofuels 12, 240. doi:10.1186/s13068-019-1529-1

Ruiz, H. A., Conrad, M., Sun, S.-N., Sanchez, A., Rocha, G. J. M., Romaní, A., et al. (2020). Engineering Aspects of Hydrothermal Pretreatment: From Batch to Continuous Operation, Scale-Up and Pilot Reactor under Biorefinery Concept. Bioresour. Tech. 299, 122685. doi:10.1016/j.biortech.2019.122685

Ruiz, H. A., Galbe, M., Garrote, G., Ramirez-Gutierrez, D. M., Ximenes, E., Sun, S.N., et al. (2021). Severity Factor Kinetic Model as a Strategic Parameter of Hydrothermal Processing (Steam Explosion and Liquid Hot Water) for Biomass Fractionation under Biorefinery Concept. Bioresour. Tech. 342, 125961. doi:10.1016/j.biortech.2021.125961

Segal, L., Creely, J. J., Martin, A. E., Jr., and Conrad, C. M. (1959). An Empirical Method for Estimating the Degree of Crystallinity of Native Cellulose Using the X-Ray Diffractometer. Textile Res. J. 29, 786-794. doi:10.1177/004051755902901003

Silva, C. O. G., Vaz, R. P., and Filho, E. X. F. (2018). Bringing Plant Cell walldegrading Enzymes into the Lignocellulosic Biorefinery Concept. Biofuels, Bioprod. Bioref. 12, 277-289. doi:10.1002/bbb.1832

Singleton, V. L., Orthofer, R., and Lamuela-Raventós, R. M. (1999). [14] Analysis of Total Phenols and Other Oxidation Substrates and Antioxidants by Means of Folin-Ciocalteu Reagent. Methods Enzymol. 299, 152-178. doi:10.1016/s00766879(99)99017-1 
Sluiter, A., Hames, A. B., RuizScarlata, R. C., Sluiter, J., Templeton, D., and Crocker, D. (2012). Determination of Structural Carbohydrates and Lignin in Biomass. Golden, CO: Laboratory Analytical Procedure, National Renewable Energy Laboratory (NREL). Version 08-03-2012.

Sun, S., Sun, S., Cao, X., and Sun, R. (2016). The Role of Pretreatment in Improving the Enzymatic Hydrolysis of Lignocellulosic Materials. Bioresour. Tech. 199, 49-58. doi:10.1016/j.biortech.2015.08.061

Travaini, R., Barrado, E., and Bolado-Rodríguez, S. (2016). Effect of Ozonolysis Pretreatment Parameters on the Sugar Release, Ozone Consumption and Ethanol Production from Sugarcane Bagasse. Bioresour. Tech. 214, 150-158. doi:10.1016/j.biortech.2016.04.102

Travaini, R., Otero, M. D. M., Coca, M., Da-Silva, R., and Bolado, S. (2013). Sugarcane Bagasse Ozonolysis Pretreatment: Effect on Enzymatic Digestibility and Inhibitory Compound Formation. Bioresour. Tech. 133, 332-339. doi:10. 1016/j.biortech.2013.01.133

Vasconcellos, V. M., Farinas, C. S., Ximenes, E., Slininger, P., and Ladisch, M. (2019). Adaptive Laboratory Evolution of Nanocellulose-producing Bacterium. Biotechnol. Bioeng. 116, 1923-1933. doi:10.1002/bit.26997

Weil, J. R., Sarikaya, A., Rau, S.-L., Goetz, J., Ladisch, C. M., Brewer, M., et al. (1998). Pretreatment of Corn Fiber by Pressure Cooking in Water. Appl. Biochem. Biotechnol. 73, 1-17. doi:10.1007/bf02788829

Ximenes, E., Farinas, C., Baldino, A., and Ladisch, M. (2021). Moving from Residual Lignocellulosic Biomass into High-Value Products: Outcomes from a Long-Term International Cooperation. Biofuels, Bioprod. Biorefin. 15 (2), 563-573. doi:10.1002/bbb.2179

Ximenes, E., Farinas, C. S., and Kim, Y., and (2017) Hydrothermal Processing in Biorefineries - Production of Bioethanol and High Added-Value Compounds of Second and Third Generation Biomass. Editors, H. L. Trajano and M. H. Thomsen (Springer International Publishing Switzerland), 181-206. 978-3-319-56456-2. doi:10.1007/978-3-319-56457-9_7

Ximenes, E., Kim, Y., Mosier, N., Dien, B., and Ladisch, M. (2011). Deactivation of Cellulases by Phenols. Enzyme Microb. Tech. 48, 54-60. doi:10.1016/j.enzmictec.2010. 09.006

Ximenes, E., Kim, Y., Mosier, N., Dien, B., and Ladisch, M. (2010). Inhibition of Cellulases by Phenols. Enzyme Microb. Tech. 46, 170-176. doi:10.1016/j. enzmictec.2009.11.001
Xiros, C., and Olsson, L. (2014). Comparison of Strategies to Overcome the Inhibitory Effects in High-Gravity Fermentation of Lignocellulosic Hydrolysates. Biomass and Bioenergy 65, 79-90. doi:10.1016/j.biombioe. 2014.03.060

Zanchetta, A., Santos, A. C. F., Ximenes, E., Nunes, C. C. C., BoscoloGomes, M. E., and Ladisch, M. R. (2018). Temperature Dependent Cellulase Adsorption on Lignin from Sugarcane Bagasse. Bioresour. Technol. 252, 143-149. doi:10.1016/ j.biortech.2017.12.061

Zhang, Q., Chen, Q., Chen, J., Wang, K., Yuan, S., and Sun, R. (2015). Morphological Variation of Lignin Biomacromolecules during AcidPretreatment and Biorefinery-Based Fractionation. Ind. Crop Prod. 77, 527-534. doi:10.1016/j.indcrop.2015.09.021

Zhou, Z., Cheng, Y., Jiang, J., and Lei, F. (2016). Characterization of Lignins from Sugarcane Bagasse Pretreated with green Liquor Combined Ethanol and Hydrogen Peroxide. BioRes 11, 3191-3203. doi:10.15376/biores.11.2. 3191-3203

Conflict of Interest: The authors declare that the research was conducted in the absence of any commercial or financial relationships that could be construed as a potential conflict of interest.

The handling editor declared a past co-authorship with the authors EX and ML.

Publisher's Note: All claims expressed in this article are solely those of the authors and do not necessarily represent those of their affiliated organizations, or those of the publisher, the editors, and the reviewers. Any product that may be evaluated in this article, or claim that may be made by its manufacturer, is not guaranteed or endorsed by the publisher.

Copyright (C) 2022 Bordignon, Ximenes, Perrone, Carreira Nunes, Kim, Boscolo, Gomes, Filho, da Silva and Ladisch. This is an open-access article distributed under the terms of the Creative Commons Attribution License (CC BY). The use, distribution or reproduction in other forums is permitted, provided the original author(s) and the copyright owner(s) are credited and that the original publication in this journal is cited, in accordance with accepted academic practice. No use, distribution or reproduction is permitted which does not comply with these terms. 